\title{
Determinasi Faktor - Faktor Indeks Pembangunan Manusia di JaWa Barat Menggunakan Regresi Data Panel
}

\author{
${ }^{1}$ Anny Suryani, ${ }^{2}$ Euis Sartika \\ ${ }^{1}$ Akuntansi, Politeknik Negeri Bandung, Jawa Barat, Indonesia \\ ${ }^{2}$ Administrasi Niaga, Politeknik Negeri, Jawa Barat, Indonesia \\ email: ${ }^{1}$ any.suryani@polban.ac.id, ${ }^{2}$ euissartika_sartika@yahoo.com
}

\begin{abstract}
The measure used in evaluating human development is the Human Development Index (HDI). The success of the development of the quality of human life can be seen from the indicator, namely HDI. The components that affect the HDI value consist of 3, namely education, health, and the feasibility of human living standards. This study aims to determine the factors that influence the HDI of cities / regencies in West Java. The predictor variables estimated to affect HDI were GRDP, health facilities (KES), and local costs for education (PEND) and the response variable was HDI. The results showed that the most appropriate regression of this study is the Fixed Effect model and the independent variables that have a significant effect on HDI are the cost of local education and health facilities. While the contribution of independent variables to the response variable was $97.74 \%$, meaning that $97.74 \%$ of the HDI was influenced by the PDRB variable, regional education costs, and health facilities, the remaining $2.26 \%$ was influenced by other factors.
\end{abstract}

Keywords: HDI, Panel Data Regression

\begin{abstract}
Abstrak. Ukuran yang digunakan dalam mengevaluasi pembangunan manusia adalah Indeks Pembangunan Manusia (IPM). Keberhasilan pembangunan kualitas hidup manusia dapat dilihat dari indikatornya, yaitu IPM. Komponen yang memengaruhi nilai IPM terdiri dari 3, yaitu pendidikan, kesehatan, dan kelayakan dari standar hidup manusia. Penelitian ini bertujuan mengetahui faktor-faktor yang berpengaruh pada IPM kota/kabupaten Jawa Barat. Variabel prediktor yang diperkirakan memengaruhi IPM adalah PDRB, sarana kesehatan (KES), dan biaya daerah untuk pendidikan (PEND)dan variabel respon adalah IPM. Hasil penelitian menunjukkan bahwa regresi paling tepat dari studi ini adalah model Fixed Effect dan variabel-variabel bebas yang berpengaruh signifikan terhadap IPM adalah biaya pendidikan daerah dan sarana kesehatan. Sedangkan Kontribusi variabel-varibel bebas terhadap variabel respon adalah sebesar 97,74\%, artinya 97,74\% dari IPM dipengaruhi oleh variable PDRB, biaya pendidikan daerah, dan sarana kesehatan, sisanya 2,26\% dipengaruhi faktor lain.
\end{abstract}

Kata Kunci : IPM, Regresi Data Panel

\section{Pendahuluan}

Human Development Index atau IPM kota/kabupaten Jabar meningkat selama jangka waktu 2010 - 2018, yakni sebesar 0,94 persen rata-rata per tahun. Peningkatan IPM kota/kabupaten Jawa Barat diperlihatkan dalam gambar 1 berikut:

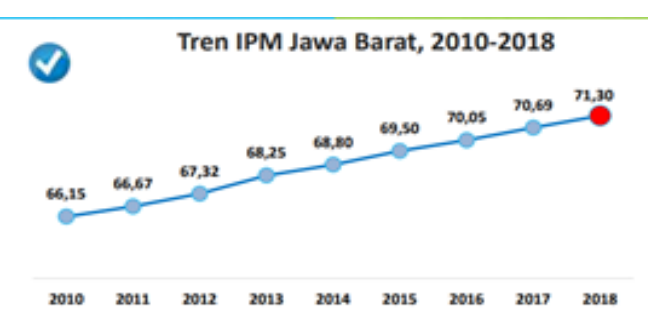

Gambar 1. Tren IPM Jawa Barat tahun 2010-2018

Pertumbuhan tertinggi terjadi di Kabupaten Karawang (1,44 \%), terendah 
di Kota Bandung (0,22 \%). Tumbuhya IPM kota/kabupaten merupakan akibat dari naiknya seluruh komponen pembentuk IPM. Beberapa IPM tumbuh cepat, sebagian lagi melambat. Kondisi ini diakibatkan oleh pertumbuhan komponen pembentuk IPM yang tidak merata di kota / kabupaten Jawa Barat. [1].

Tabel berikut memperlihatkan predikat pertumbuhan Hasil Indeks Pembangunan Manusia untuk kota/kabupaten Jabar tahun 2017 sd 2018:

Tabel 1. Pertumbuhan IPM Jawa Barat Tahun $2017-2018$

\begin{tabular}{|l|l|l|l|}
\hline \multicolumn{2}{|l|}{ Tertinggi } & \multicolumn{2}{|l|}{ Terendah } \\
\hline Daerah & $\%$ & Daerah & $\%$ \\
\hline Kota Cianjur & 1,44 & $\begin{array}{l}\text { Kota } \\
\text { Banjar }\end{array}$ & 0,65 \\
\hline Kota Garut & 1,39 & $\begin{array}{l}\text { Kota } \\
\text { Depok }\end{array}$ & 0,58 \\
\hline $\begin{array}{l}\text { Kab. } \\
\text { Tasikmalaya }\end{array}$ & 1,34 & Cirebon & 0,47 \\
\hline
\end{tabular}

Berdasarkan tabel 1, dapat ditunjukkan bahwa status pembangunan kota/kabupaten Jawa barat dibagi ke dalam 3 kelompok wilayah, yaitu:

1. Kelompok "sangat tinggi" dengan nilai IPM > 80 (Kota Bandung,Kota Depok, dan Kota Bekasi)

2. Kelompok "tinggi" dengan nilai $70<\mathrm{IPM}<90$ (9 kab/kota)

3. Kelompok "sedang" dengan nilai $60<$ IPM $<70$ (15 kab/kota)

Perbedaan predikat ini tidak terlepas dari adanya perbedaan pertumbuhan komponen- komponen IPM pada kota / kabupaten di Jawa barat. Adanya kesenjangan capaian IPM dan komponen-komponen IPM antar kota /kabupaten inilah yang menjadi permasalahan. Umur Harapan Hidup saat lahir (UHH), digunakan sebagai indikasi pengukuran tingkat kesehatan Jawa Barat tahun 2017 mencapai 72,47 tahun, artinya rata-rata bayi yang lahir akan hidup selama 72,47 tahun. Harapan Lama Sekolah (HLS) dan Rata-rata Lama Sekolah (RLS) digunakan sebagai indicator pengukuran dimensi pendidikan diukur dengan indicator. Rata-rata pengeluaran per kapita per tahun digunakan sebagai indikator pengukuran komponen Standar Hidup Layak dalam satuan rupiah yang distandarkan dengan paritas daya beli (Purchasing Power Parity).

\section{Tujuan penelitian:}

1. Mengetahui faktor mana saja yang memengaruhi IPM secara signifikan bagi kota/kabupaten di Jawa Barat, baik pengaruh secara individu maupun secara bersama-sama.

2. Mengetahui bentuk pemodelan regresi data panel yang paling tepat menggambarkan factorfaktor yang memengaruhi Indeks Pembangunan Manusia kota/kabupaten Jawa barat berdasarkan beberapa alat pengujian data panel.

\section{Tinjauan Teori}

Penelitian yang dilakukan oleh Latuconsina.ZMY (2017) menyatakan bahwa jumlah sarana kesehatan, bidan, dan kepadatan penduduk memengaruhi IPM Malang. Sedangkan Juraidah. A (2018) menyebutkan bahwa angka kematian bayi, angka partisipasi murni $\mathrm{SD}$, dan angka perbandingan antara banyaknya murid dari SMA/MA dengan banyaknya penduduk usia sekolah pada jenjang yang sama (\%), angka beban ketergantungan, dan rata-rata kemiskinan berpengaruh pada IPM kota Jabar. Keterbaruan penelitian ini adalah digunakannya data terkini yakni 2015 sd 2018, analisis data yang digunakan 
adalah regresi data panel dengan objek penelitian adalah kota/kabupaten Jabar. Variabel respon adalah IPM, sedangkan variable bebas adalah PDRB, Pendidikan, dan sarana Kesehatan.

\section{Indeks Pembangunan Manusia}

Definisi dari pembangunan manuasia adalah adalah suatu proses untuk memperbesar pilihan-pilihan bagi manusia " a process of enlarging peoples's choices", menurut United Nations Development Program (UNDP) [3]. Aspek-aspek pembangunan manusia berdasarkan pemikiran konsep pembangunan manusia adalah sebagai berikut : a) Penduduk harus diutamakan sebagai pusat perhatian pembangunan manusia; b) Pembangunan manusia bukan hanya untuk meningkatkan pendapatan mereka, melainkan untuk memperbesar pilihan-pilihan bagi penduduk,; C) Pembangunan manusia tidak hanya tertuju pada upaya peningkatan kemampuan/kapasitas manusia, melainkan juga peningkatan upaya pemanfaatan kemampuan/kapasitas manusia tersebut secara optimal; d) Empat pilar pokok yang mendukung pembangunan manusia adalah: produktifitas, pemerataan, kesinambungan dan pemberdayaan. Pembangunan manusia juja sebagai fondasi untuk mencapai tujuan. pembangunan dan: peluang hidup (longevity), pengetahuan (knowledge) dan hidup layak (living standards). [1].

\section{PDRB (Produk Daerah Regional Bruto)}

Jumlah total dari nilai tambah barang dan jasa yang dapat dihasilkan berdasarkan kegiatan perekonomian di seluruh wilayah dalam periode tahun tertentu yang pada umumnya dalam jangka waktu satu tahun merupakan definisi dari PDRB. Harga dari PDRB yaitu: a) harga dari suatu barang dan jasa yang dihitung menggunakan harga pada tahun tertentu yang dijadikan tahun dasar untuk harga tersebut yang disebut sebagai PDRB harga konstan, b) harga dari suatu barang dan jasa yang dihitung menggunakan berlaku merupakan nilai dari suatu barang dan jasa yang dihitung menggunakan harga yang berlaku pada tahun tersebut dikenal dengan istilah PDRB harga yang berlaku. PDRB merupakan salah satu indikator yang dapat menggambarkan tingkat pertumbuhan ekonomi. Berdasarkan data PDRB atas dasar harga konstan dapat dihitung pertumbuhan ekonomi yang menggambarkan pertambahan rill kemampuan ekonomi suatu wilayah [11].

\section{Pendidikan}

Usaha untuk memajukan timbulnya budi pekerti yang dilakukan dalam rangka menyiapkan peserta didik agar mampu mengembangkan potensi yang dimiliki secara menyeluruh dalam memasuki kehidupan di masa depan merupakan penegertian dari Pendidikan. UNDP mengembangkan konsep pendidikan sebagai aspek penting dalam IPM.Untuk mengembangkan aspek Pendidikan digunakan dua indicator, yaitu: 1) Angka Melek Huruf (AMH) Penduduk usia 15 tahun keatas, 2) Ratarata Lama Sekolah (RLS), untuk mengukur rata-rata lama sekolah digunakan tiga vaiabel, yaitu partisipasi sekolah, tingkat/kelas yang sedang/atau pernah dijalani, dan jenjang pendidikan tertinggi yang ditamatkan. Manfaat pendidikan antara lain: membentuk sumber daya manusia yang mempunyai kualitas, pengetahuan dan ketrampilan serta mempunyai penguasaan teknologi. Selain itu, Pendidikan dapat mengembangkan iklim bisnis yang sehat dan kondusif bagi pertumbuhan ekonomi. Pendidikan juga membuka jalan menuju kemajuan dan tercapainya kesejahteraan sosial ekonomi, 
Pendidikan dapat meningkatkan kemampuan sebuah negara untuk memanfaatkan teknologi modern dan untuk meneingkatkan kemampuan dan kapasitas agar tercipta pertumbuhan serta pembangunan yang terus-menerus dan berkesinambungan. [12].

\section{Sarana Kesehatan}

Meningkatkan kualitas sumber daya manusia, meningkatkan kualitas kehidupan, meningkatkan usia harapan hidup dan mempertinggi. kesehatan masyarakat merupakan fokus dan arah pembangunan Kesehatan. Dukungan fasilitas kesehatan yang memadai, sangat dibutuhkan untuk tercapainya kesehatan yang prima. Definisi kesehatan menurut WHO, kesehatan merupakan sebuah kondisi kesejahteraan fisik, mental dan sosial, tidak hanya bebas dari penyakit dan fisik yang lemah. Pembangunan kesehatan harus menyeluruh mencapai semua aspek kehidupan manusia secara terus menerus, terpadu, dan mempunyai arah. Sedangkan pembangunan infrastruktur kesehatan, harus mampu meningkatkan kualitas sumber daya manusia baik dari sisi kuantitas maupun kualitas, sehingga akan meningkatkan Indeks Pembangunan Manusia.

\section{Regresi Data Panel}

Model hubungan yang menggambarkan pengaruh variable bebas terhadap variabel respon dalam beberapa individu yang diamati berdasarkan objek penelitian selama periode waktu tertentu. Model umum dari regresi data panel dinotasikan sebagai berikut [13]:

$$
y_{i z}=\alpha+X_{i z} \beta+\varepsilon_{i}
$$

Keterangan:

$\mathrm{i} \quad=1,2, \ldots, \mathrm{n} ; \mathrm{t}=1,2, \ldots, \mathrm{T}$

yit = variabel respon individu ke-i

untuk periode waktu ke- $t$

$\alpha \quad=$ intersep
$\mathrm{X}^{\prime}$ it $=$ variabel prediktor individu ke-i untuk periode waktu ke- $\mathrm{t}$

$\beta=$ parameter koefisien arah regresi (slope) berukuran $\mathrm{k} \mathrm{x} 1$

$\varepsilon_{i t} \quad=$ error regresi individu ke-i untuk periode waktu ke-t

\section{Model Regresi Data Panel}

1. Common Effect Model (CEM) adalah model regresi data panel yang mempunyai asumsi bahwa nilai intersep dan slop regresi untuk semua unit cross section dan time series adalah sama [14]. Metode Ordinary Least Square (OLS) digunakan untuk mengestimasi model CEM.

2. Fixed Effect Model (FEM) adalah model regresi data panel yang mempunyai asumsi bahwa nilai intersep dari unit cross section atau time series berbeda, tetapi mempunyai nilai slope yang tetap [15]. Metode Least Square Dummy Variable (LSDV) digunakan untuk mengestimasi model FEM.

3. Random Effect Model (REM) adalah model regresi data panel yang mempunyai asumsi bahwa perbedaan intersep pada unit cross section merupakan variabel acak [16].

\section{Hipotesis Penelitian}

Pengujian parsial:

Ho: $\beta$ PDRB $=0$; Ha: $\beta$ PDRB $\neq 0$

Ho: $\beta$ PEND $=0$; Ha: $\beta$ PEND $\neq 0$

Ho: $\beta$ KES $=0$; Ha: $\beta$ KES $\neq 0$

Ho ditolak artinya terdapat pengaruh variable bebas terhadap variable respon secara individu, jika nilai Prob (F-statistic) lebih kecil dari 0,05, dalam hal lain Ho diterima.

Pengujian Simultan:

Ho: $\beta$ PDRB $=\beta$ PEND $=\beta$ KES $=0$ Ha: (minimal salah satu tanda $\neq$ ) 
Ho ditolak artinya terdapat pengaruh variable-variabel bebas terhadap variable respon secara bersamasama, jika $F$ hitung lebih kecil dari $F$ tabel, atau nilai Prob(F-statistic) kurang dari 0,05, dalam hal lain Ho diterima.

Untuk melihat besarnya
pengaruh digunakan koefisien determinasi (R2).

\section{Pemilihan Model Terbaik}

\section{Uji Chow}

Pemilihan model terbaik diantara CEM dan FEM digunakan uji Chow.

Hipotesis:

Ho: Model CEM atau model Pool Least

Square (Restricted)

H1: Model Fixed Effect

Statistik uji yang digunakan:

$$
F_{h i t}=\frac{\left(R S S_{1}-R S S_{2}\right) /(K-1)}{R S S_{2} /(K T-K-P)} \sim F_{(\alpha,(K-1),(K T-K-P))}
$$

Dimana:

K adalah banyaknya kota/kabupaten ;

$\mathrm{T}$ adalah periode waktu observasi ;

$\mathrm{P}$ adalah parameter dalam fixed effect ;

$\mathrm{RSS}_{1}$ : residual sum squares of common effects model pertama;

$\mathrm{RSS}_{2}$ : residual sum squares of common effects model kedua;

Hipotesis

H1: Fixed Effect

Ho: Random Effect

Statistik Uji :

$$
\begin{aligned}
& W=\chi_{(P)=\left[b-\beta^{\prime}\right.}^{2} \varphi^{-1}[b-\beta] \\
& \varphi=\operatorname{Var}[b]-\operatorname{Var}[\beta]
\end{aligned}
$$

Dimana: b adalah parameter (tanpa intersep) Random Effect dan $\beta$ adalah parameter Fixed Effect menggunakan LDVD. $\operatorname{Var}[\mathrm{b}]$ adalah matriks kovarian parameter (tanpa intersep) Random Effect dan Var $[\beta]$ adalah matrisk kovarian parameter Fixed Effect, $\mathrm{P}$ adalah jumlah variable bebas.

Kriteria uji : jika nilai $\mathrm{W}>\chi^{2}{ }_{(P)}$ maka model terpilih adalah model FEM.

\section{Uji Lagrange Multiplier}

Hipotesis:

Ho: CEM

H1: REM

Uji LM digunakan untuk memguji Random Effect model yang didasarkan pada nilai residual dari model Common Rffect.

Statistik Uji

$$
\begin{aligned}
& L M=\frac{K T}{2(T-1)}\left[\frac{\sum_{i=1}^{K}\left[\sum_{t=1}^{T} e_{i t}\right]^{2}}{\sum_{i=1}^{K} \sum_{t=1}^{T} e_{i t}{ }^{2}}-1\right]^{2} \sim \chi^{2} \alpha, 1 \\
& \mathrm{~K} \text { adalah banyaknya }
\end{aligned}
$$
kota/kabupaten , $\mathrm{T}$ adalah jumlah periode waktu dan $\mathrm{e}_{\text {it }}$ adalah Common Effect Model.

Kriteria uji : jika $\mathrm{LM}>\chi^{2}{ }_{\alpha, 1}$ maka model terpilih adalah REM.

\section{Metode}

Penelitian ini menggunakan data sekunder kuantitatif yang diperoleh dari BPS Jawa Barat periode 2015 sd 2018 dan analisis data yang digunakan adalah panel data regresion. Variabel respon yang digunakan adalah Indeks Pembangunan Manusia (IPM) dalam satuan point. Variabel prediktor adalah Pendapatan daerah (PDRB) dalam satuan milyar, Sarana Kesehatan (KES) dalam satuan unit, dan Biaya pendidikan daerah (PEND) dalam satuan milyar.

Berikut tahapan regresi Data Panel menggunakan software Eviews 10:

Langkah 1 Menentukan model regresi data panel, dengan tahapan sebagai berikut:

1. Uji Chow untuk memilih model terbaik antar CEM dan FEM, jika Ho diterima maka model terpilih adalah CEM, jika ditolak maka model terpilih adalah FEM.

2. Uji Hausmen untuk memilih model terbaik antar FEM dan CEM, jika Ho diterima maka model terpilih adalah REM, jika 
ditolak maka model terpilih adalah FEM.

3. Uji Lagrange Multiplier untuk memilih model terbaik antara CEM dan REM, jika Ho dierima maka model terpilih adalah CEM, jika ditolak maka model terpilih adalah REM.

4. Menentukan metode estimasi parameter yang tepat dengan melihat struktur varians-covarian dan korelasi antar kota/kabupaten dari residualnya menggunakan uji LM (Langrange Multiplier). Apabila model yang terpilih adalah model REM, maka tidak perlu dilakukan pengujian untuk menentukan metode estimasi yang terbaik.

Langkah 2 Menguji asumsi model regresi, dengan tahapan sebagai berikut:

1. Uji Normalitas menggunakan Jarque-Bera

2. Uji Multikolinearitas menggunakan nilai VIF

3. Uji Heterokedastisitas

4. Uji Autokorelasi menggunakan Durbin Watson

Langkah 3 Melakukan uji Estimasi model, dengan tahapan sebagai berikut:

1. Uji estimasi model secara individu / parsial menggunakan uji t.

2. Uji estimasi model secara bersama-sama atau simultan menggunakan uji F, jika Prob(Fstatistic) < 0,05, dapat disimpulkan bahwa variablevariabel bebas secara simultan memengaruhi variable respon secara signifikan.

3. Uji Chi Square $\left(\mathrm{R}^{2}\right)$

4. Uji kebaikan model

\section{Hasil dan Pembahasan}

Model hubungan antara varibel pada data panel dari penelitian ini dirumuskan sebagai berikut:

$\mathrm{IPM}=\mathrm{f}(\mathrm{PDRB}, \mathrm{PEND}, \mathrm{TK}, \mathrm{KES})$

dengan persamaan:

Keterangan:

Yit = IPM kota/kabupaten i, tahun ke t

$\mathrm{i}=1,2,3, \ldots, \mathrm{N}$ (kota/kabupaten)

$\mathrm{t}=1,2,3, \ldots . . \mathrm{T}$ (tahun)

$\beta 0=$ Intercep.

$\beta 1=$ koefisien PDRB

$\beta 2=$ koefisien PEND

$\beta 4=$ koefisien $\mathrm{KES}$

PDRBit=PDRB kota/kabupaten ke-i tahun ke-t

PENDit=PEND kota/kabupaten ke-i tahun ke-t

KESit=KES kota/kabupaten ke-i tahun ke-t

Berdasakan output Eviews 10 diperoleh hasil deskriptif data penelitian adalah:

Tabel 2. Statistika Deskriptif

\begin{tabular}{|c|c|c|c|c|}
\hline & IPM & PDRB & PEND & KES \\
\hline & 70.0257 & 52262.8 & 957.522 & 13.8240 \\
Mean & 4 & 6 & 5 & 7 \\
\hline & 69.1500 & 27963.1 & 971.115 & 9.00000 \\
Median & 0 & 4 & 0 & 0 \\
\hline & 81.0600 & 372652. & 2429.34 & 64.0000 \\
Maximum & 0 & 5 & 0 & 0 \\
\hline & 62.4200 & 2624.24 & 153.220 & 0.00000 \\
Minimum & 0 & 0 & 0 & 0 \\
\hline & 4.91934 & 62388.7 & 490.644 & 13.6517 \\
Std. Dev. & 1 & 7 & 1 & 6 \\
\hline & 0.74421 & 2.41608 & 0.57146 & 1.83895 \\
Skewness & 5 & 4 & 2 & 7 \\
\hline & 2.67417 & 9.62832 & 2.95214 & 6.17239 \\
Kurtosis & 4 & 3 & 7 & 1 \\
\hline Jarque- & 10.4471 & 302.780 & 5.88855 & 106.160 \\
Bera & 4 & 3 & 1 & 0 \\
\hline Probabilit & 0.00538 & 0.00000 & 0.05264 & 0.00000 \\
y & 8 & 0 & 0 & 0 \\
\hline & 7562.78 & 5644389 & 1 & 1493.00 \\
Sum & 0 &. & 03412.4 & 0 \\
\hline
\end{tabular}

Berdasarkan ukuran rata-rata, dapat ditunjukkan bahwa selama lima tahun berturut-turut dari tahun $2015 \mathrm{sd}$ 2018, kabupaten / kota mempunyai Jawa Barat mempunyai nilai IPM dengan ratarata $70,025 \%$, IPM mencapai nilai 
maksimum pada $81,06 \%$ dan minimum pada $62,42 \%$. Sedangkan untuk rata-rata nilai PDRB mencapai Rp 52.262,86 milyar dengan nilai maksimum Rp 372 . 652,5 milyar dan nilai minimum mencapai Rp 2.624,240 milyar. Untuk anggaran pendidikan daerah, selama lima tahun berturut-turut, kabupaten/ kota di Jawa Barat mencapai nilai ratarata $\operatorname{Rp} \operatorname{Rp} 957.522,5$ milyar dengan nilai minimum adalah Rp 153.220,0 milyar.

\section{Hasil Output CEM}

Tabel 3. Tabel Hasil CEM

\begin{tabular}{|c|c|}
\hline \multicolumn{2}{|c|}{ Variable CoefficientStd. Error t-Statistic Prob. } \\
\hline $\mathrm{X} 1$ & - \\
\hline$(\mathrm{PDRB})$ & $-6.01 E-06$ 8.99E-06 0.668796 0.5051 \\
\hline $\mathrm{X} 2$ & - \\
\hline (PEND) & -0.0024950 .0009672 .5806770 .0113 \\
\hline $\mathrm{X} 3($ & \\
\hline KES) & 0.2317320 .0365126 .3467080 .0000 \\
\hline $\mathrm{C}$ & 69.525200 .90396276 .911670 .0000 \\
\hline
\end{tabular}

Tabel 4. FEM

\begin{tabular}{crrrr}
\hline \hline & $\begin{array}{c}\text { Coefficien } \\
\text { Variable }\end{array}$ & $\begin{array}{c}\text { Std. } \\
\text { Error }\end{array}$ & $\begin{array}{r}\mathrm{t}- \\
\text { Statistic }\end{array}$ & Prob. \\
\hline \hline & & 0.52491 & 137.294 & \\
$\mathrm{C}$ & 72.06780 & 4 & 6 & 0.0000 \\
& & & - & \\
& & $2.56 \mathrm{E}-$ & 0.20605 & \\
PDRB & $-5.28 \mathrm{E}-07$ & 06 & 8 & 0.8373 \\
& & 0.00046 & 3.68881 & \\
PEND & -0.001731 & 9 & 2 & 0.0004 \\
& & 0.01212 & 2.13153 & \\
KES & -0.025850 & 8 & 1 & 0.0362 \\
\hline \hline
\end{tabular}

Effects

Specification

Cross-section fixed (dummy variables)

\begin{tabular}{|c|c|c|}
\hline R- & Mean & 70.0257 \\
\hline $\begin{array}{l}\text { squared } \\
\text { Adjusted }\end{array}$ & 0.983541 dependent var & 4 \\
\hline R- & S.D. dependent & 4.91934 \\
\hline $\begin{array}{l}\text { squared } \\
\text { S.E. of }\end{array}$ & $0.977422 \mathrm{var}$ & 1 \\
\hline gressio & $\begin{array}{l}\text { Akaike } \\
0.739184 \text { criterion }\end{array}$ & $\begin{array}{r}2.46359 \\
5\end{array}$ \\
\hline
\end{tabular}

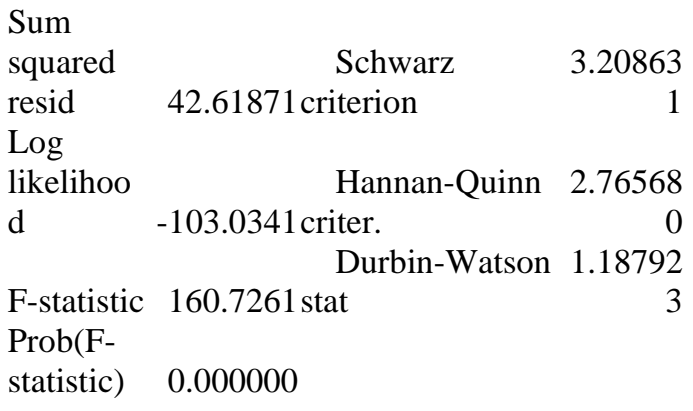

Tabel 5. Uji Chow

Effects Test Statistic d.f. Prob.

Cross-section F $217.602353(26,78) 0.0000$

Berdasarkan hipotesis Uji Chow:

Ho: Model paling tepat adalah CEM H1: Model paling tepat adalah FEM

Berdasarkan tabel 3, dapat ditunjukkan nilai Prob(F-statistic) Cross Section $F=0,0000<0,05$, sehingga kita menolak Ho, artinya model yang tepat adalah FEM.

Langkah berikutnya, melakukan uji Hausman untuk memperoleh model paling tepat antara FEM dan REM Output dari Eviews 10 memberikan hasil sebagai berikut

Tabel 6. Random Effect Model

\begin{tabular}{|c|c|c|}
\hline Variable & Coefficient & $\begin{array}{cc}\text { Std. } & \mathrm{t}- \\
\text { Error } & \text { Statistic Prob. }\end{array}$ \\
\hline $\mathrm{C}$ & \multirow{2}{*}{\multicolumn{2}{|c|}{$\begin{array}{l}71.670220 .85853083 .480190 .0000 \\
6.81 \mathrm{E}-072.51 \mathrm{E}-060.2708980 .7870\end{array}$}} \\
\hline PDRB & & \\
\hline PEND & \multicolumn{2}{|c|}{$-0.0015600 .0004473 .4878550 .0007$} \\
\hline KES & \multicolumn{2}{|c|}{$-0.0134630 .0118121 .1397980 .2570$} \\
\hline $\begin{array}{l}\text { Cross-sect } \\
\text { Idiosyncra }\end{array}$ & $\begin{array}{l}\text { ion random } \\
\text { tic random }\end{array}$ & $\begin{array}{l}3.6545540 .9607 \\
0.7391840 .0393\end{array}$ \\
\hline
\end{tabular}

Tabel 7. Uji Hausman

\begin{tabular}{|c|c|}
\hline Test Summary & $\begin{array}{l}\text { Chi-Sq. } \\
\text { Statistic }\end{array}$ \\
\hline $\begin{array}{l}\text { Cross-section } \\
\text { random }\end{array}$ & 27.497968 \\
\hline $\begin{array}{l}\text { Hipotesis } \\
\text { sebagai berikut: }\end{array}$ & uji Hausman adalah \\
\hline Ho: Model yang s & sesuai REM \\
\hline
\end{tabular}


H1: Model yang sesuai FEM

Berdasarkan tabel 5, dapat ditunjukkan bahwa nilai Probabilitas $=0,0000<0,05$ sehingga menolak Ho, artinya Model yang sesuai adalah FEM. Fixed effects merupakan sebuah model regresi yang

memiliki intercept untuk setiap subjek cross section, tetapi tidak ada perubahan untuk slope-nya.

Sehingga selanjutnya dilakukan uji asumsi untuk model FEM.

\section{Uji Normalitas}

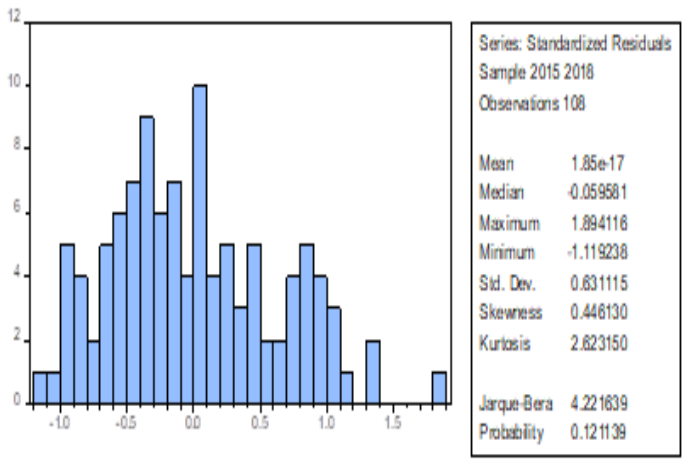

Gambar 2. Uji Normalitas

Berdasarkan gambar 2, dapat ditunjukkan bahwa nilai probabilitas $=0,121139>0,05$ maka Ho diterima artinya data berdistribusi normal.

Ho: Residual berdistribusi Normal H1: Residual tidak berdistribusi normal

Dapat disimpulkan bahwa asumsi kenormalan dipenuhi.

\section{Uji Multikolinearitas}

Nilai korelasi antara variabel bebas ditunjukkan dalam tabel berikut

Tabel 8. Korelasi antar Variabel

\begin{tabular}{|l|c|c|c|}
\hline & PDRB & PEND & KES \\
\hline $\begin{array}{l}\text { PDR } \\
\text { B }\end{array}$ & 1 & $\begin{array}{c}0.55399 \\
4\end{array}$ & $\begin{array}{c}0.6102456 \\
1\end{array}$ \\
\hline PEN & 0.553994 & 1 & 0.3510278 \\
D & 8 & & 7 \\
\hline KES & $\begin{array}{c}0.610245 \\
6\end{array}$ & $\begin{array}{c}0.35102 \\
7\end{array}$ & 1 \\
\hline
\end{tabular}

Berdasarkan tabel 8, dapat ditunjukkan bahwa nilai hubungan variable-variabel bebas semuanya di bawah nilai 0,8 , artinya tidak terjadi korelasi yang signifikan antara variabelvaribel bebas. Arinya, asumsi multikolinearitas dapat dipenuhi.

\section{Uji Heterokedastisitas}

Tabel 9. Uji Heterokedastisitas

\begin{tabular}{|c|c|c|}
\hline & Coeff & \begin{tabular}{r|r|r} 
Std. & $\mathrm{t}$ & \\
Error & Statistic & Prob. \\
\end{tabular} \\
\hline 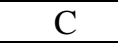 & 0.4 & 0.0800055 .0626760 .0000 \\
\hline PDF & & 7185 \\
\hline & & 0.3399 \\
\hline KF & 0 & $0.003232 \mid 0.363$ \\
\hline
\end{tabular}

Berdasarkan tabel 9, dapat ditunjukkan bahwa nilai probabilitas masing-masing variabel bebas semuanya lebih besar dari 0,05. Hal ini berarti bahwa tidak terjadi heterokedastisitas pada data penelitian, jadi asumsi heterokedastisitas dapat dipenuhi.

\section{Uji Autokorelasi}

Nilai $d w=1,187923$, berdasarkan nilai yang tertera dalam tabel durbin watson jika jumlah data adalah 27 dan banyak variable bebas adalah 3 , diperoleh nilai batas bawah (dl) adalah 1,1805 dan nilai

Batas atas (du) adalah 1,6503 serta nilai $(4-d u)=2,3479$. Karena nilai $\mathrm{dw}=1,187932$ maka nilai $\mathrm{dw}$ terletak diantara dl dan du, artinya Nilai dw= 1,187923 , berdasarkan tabel DW untuk jumlah variable 127 dan banyak variable bebas 3, didapat nilai batas bawah (dl) adalah 1,1805 dan nilai batas atas adalah 1,6503 serta nilai $(4-d u)=2,3479$, tidak dapat disimpulkan, sehingga kondisi ini hrs diatasi. Untuk mengatasinya digunakan Cochraneorcutt, dan diperoleh hasil sebagai berikut:

Nilai Durbin Watson hasil perbaikan menjadi 1,836665 dan terletak dalam interval nilai du dan 4-du, dan dapat diartikan bahwa tidak tedapat autokorelasi. Artinya asumsi autokorelasi dipenuhi. Berdasarkan 
tabel Fixed Effect model dapat ditunjukkan bahwa:

$\mathrm{IPM}=72.06780 \quad-5.28 \mathrm{E}-07 \quad \mathrm{PDRB} \quad-$ 0.001731 Biaya pendidikan daerah $0.025850 \mathrm{Kes}$

Interpretasi:

Setiap variable-variabel bebas meningkat satu satuan akan menurunkan nilai IPM.

\section{Uji Estimasi Koefisien Model} Fixed Effect

Berdasarkan uji parsial, variable X1(PDRB) tidak berpengaruh terhadap variable respon (IPM), hal ini ditunjukkan oleh nilai probabilitas yang kurang dari 0,05. Sedangkan variabel variabel X2 (biaya pendidikan daerah) dan X3(sarana kesehatan) memengaruhi Indeks Pembangunan Manusia secara signifikan, karena kedua variable tersebut memberikan nilai probabilitas kurang dari 0,05 . Kontribusi variabelvaribel bebas terhadap variabel Indeks Pembangunan Manusia adalah sebesar $97,74 \%$, artinya $97,74 \%$ dari variable Indeks Pembangunan Manusia dipengaruhi oleh PDRB, biaya pendidikan daerah, dan sarana kesehatan, sisanya 2,26\% dipengaruhi faktor lain.

\section{Kesimpulan dan Saran}

Dari analisis yang sudah dilakukan, dapat disimpulkan bahwa:

Model regresi data panel yang paling tepat pada penelitian ini adalah model Fixed Effect (FEM). Variabel bebas yang memberikan pengaruh signifikan secara individual terhadap variable respon dalam hal ini Indeks Pembangunan Manusia adalah Biaya Pendidikan Daerah dan Sarana Kesehatan. Sedangkan PDRB tidak memberikan pengaruh terhadap variable IPM, karena nilai probabilitasnya lebih dari 0,05. Sebagai saran, diharapkan ada penelitian lain yang menggunakan variable bebas bidang Pendidikan dan bidang Kesehatan dalam komponen yang berbeda, misalnya keberadaaan sumber daya manusia bidang kesehatan, sarana Kesehatan di rumah sakit-rumah sakit daerah terpencil, alokasi dana Pendidikan di daerah terpencil untuk semua tingkatan pendidikan, dan lain sebagainya.

\section{DAFTAR PUSTAKA}

Badan Pusat Statistik (BPS) Jawa barat, 2017

Galamedia News, "Rilis BPS, IPM Jabar 2019 Capai 72,03," didownload 29 april 2020.

United Nations Development Programme (UNDP), 1990.

Evan. E. (2010). "Analisis Disparitas IPM Kabupaten/Kota Di Provinsi Jawa Barat dan Faktor-Faktor yang Mempengaruhi Capaiannya". Tesis. Fakultas Ekonomi Magister Perencanaan Dan Kebijakan Publik Kekhususan Manajemen Strategis Sektor Publik UI.

Rachmat. D, Bachtiar, N. (2015). "Analisis Faktor-Faktor yang Mempengaruhi Indeks Pembangunan Manusia Di Sumatera Barat". Repository UNAND

Dwiky S (2017), "Determinasi FaktorFaktor yang Mempengaruhi IPM Di Provinsi Jawa Barat Periode 20132017". Repository UNAND

Latuconsina. ZMY. (2017). "Analisis Faktor-faktor yang Mempengaruhi Indeks Pembangunan Manusia Kabupaten Malang Berbasis Pendekatan Perwilayahan dan Regresi Panel". Journal of Regional and Rural Development Planning

Juliarini.A.(2018)." Kinerja pendapatan Daerah Terhadap Indeks Pembangunan Manusiastudi Kasus Provinsi Di Pulau Jawa”. Simposium Nasional Keuangan Negara 2018.

Zia. A. Z. (2018)." Analisis Faktor yang mempengaruhi Indeks Pembangunan 
160 Anny Suryani, et al.

Manusia Provinsi Jawa Timur". Skripsi thesis, Universitas Airlangga. Ayu.R.(2018)." Analisis Faktor-Faktor yang Mempengaruhi Indeks Pembangunan Manusia Provinsi Jawa Tengah periode Tahun 20062016". Jurnal UII Jogyakarta.

Fauziah, Syifa. (2020)“Analisis FaktorFaktor yang Mempengaruhi Indeks Pembangunan Manusia Di Provinsi Jawa Barat Periode 20152018".Repository UMY.

Todaro, M. 2006. Pengembangan Ekonomi Dunia Ketiga. Edisi Kedelapan. Jakarta:

Penerbit Erlangga

Baltagi, Econometric Analysis of Panel Data. John Wiley \&. Sons, Ltd, 2005.

D. Hanum, "Studi Tentang Seemingly Unrelated Regression untuk Data Panel Dengan Model Gravitasi Studi Kasus Perdagangan Ekspor Indonesia," 2015.

W. H. Greene, Econometric Analysis. 2008.

D. N. Gujarati, Basic Econometrics, 4th ed. Tata Mc Graw Hill, 2004 